Shachaf, P., Oltmann, M. S., \& Horowitz, S. (2008). Service equality in virtual reference. Journal of the American Society for Information Science and Technology, 59(4), 535-550.

\title{
SERVICE EQUALITY IN VIRTUAL REFERENCE
}

\author{
Pnina Shachaf \\ School of Library and Information Science \\ Indiana University \\ 1320 East 10th Street, LI005A \\ Bloomington, IN 47405-3907 \\ Phone: (812) 856-1587 \\ Fax: (812) 855-6166 \\ E-mail: shachaf@indiana.edu \\ Shannon M. Oltmann \\ School of Library and Information Science \\ Indiana University \\ 1320 East 10th Street, LI001 \\ Bloomington, IN 47405-3907 \\ Phone: (812) 855-2018 \\ Fax: (812) 855-6166 \\ E-mail: soltmann@indiana.edu \\ Sarah M. Horowitz \\ Thomas Tredway Library \\ Augustana College \\ 639 38th Street \\ Rock Island, IL 61201 \\ Phone: (309) 794-8814 \\ Fax: (309) 794-7640 \\ Email: sarahhorowitz@augustana.edu
}

\begin{abstract}
Research is divided about the potential of e-service to bridge communication gaps, particularly to diverse user groups. According to the existing body of literature, eservice may either increase or decrease the quality of service received. This study analyzes the level of service received by different genders and ethnic groups when academic and public librarians answer 676 online reference queries. Quality of e-service was evaluated along three dimensions: timely response, reliability, and courtesy. This study found no significant differences among different user groups along any of these dimensions, supporting the argument that the virtual environment facilitates equitable service and may overcome some challenges of diverse user groups.
\end{abstract}

\section{INTRODUCTION}

According to the most recent US Census, $77 \%$ percent of the population were White; $12 \%$ were Black or African American; $4 \%$ were Asian; and $14 \%$ of the people in United States were Hispanic (people of Hispanic origin may be of any race). Twelve percent of 
the people living in the United States in 2004 were foreign born and $19 \%$ spoke a language other than English at home. These groups are making growing use of the internet; $73 \%$ of Whites (non-Hispanic), $79 \%$ of (English speaking) Hispanics, and $60 \%$ of Blacks (non-Hispanics) are using the internet (Pew Internet \& American Life Project, 2005). These diverse user groups make use of online services and in particular online library services. Service discrimination has been a major social concern in the face-toface environment and reports on discrimination in public accommodation are not rare. For example, Feagin (1991) reported that $79 \%$ of discriminatory actions against African Americans in public accommodations involved rejection or poor service and LaPiere (1934), in the pre- Civil Rights Act era, reported that formal written requests for service were rejected more than in-person requests by minorities.

Research has shown that because computer-mediated communication decreases social cues and reduces social presence, it may have a democratizing effect on communication resulting in, for example, status equalization (Sproull \& Keisler, 1986). Similarly, claims that the use of email can mediate challenges of cultural diversity and that online heterogeneity improves group performance have been made (e.g., Daily \& Steiner, 1998; Daily, Whatley, Ash, \& Steiner, 1996; Shachaf, 2005b). Thus, online discrimination may be less common due to the ability of potential targets to eliminate social and group identification cues and to remain anonymous; the relative absence of social cues may mean greater equality of services in the virtual environment (Glaser \& Kahn, 2005).

Conversely, the online environment reproduces social and other inequalities (e.g., the digital divide) and enables and supports uninhibited behaviors. Douglas and McGarty (2001) claimed that in the virtual environment, people can become less selfaware and less likely to monitor their behavior and therefore more likely to act on impulses that would normally be inhibited. Thus, discrimination is more likely to be expressed overtly due to the anonymous, spontaneous, impersonal, and uninhibited nature of computermediated communication (Glaser \& Kahn, 2005). It is possible, therefore, that in the virtual environment subjective bias will be similar to the pre-civil rights era or that greater inequality will arise. While e-services providers will not be likely to deny some resources or services on the basis of group membership, they may find an excuse to behave discriminatorily at the moment (Crosby, Bromley, \& Sax, 1980). Although studies that report online discriminatory behaviors against minorities are scarce (Bushman \& Bonacci, 2004; Shachaf, 2005a), the present study assumes that it is possible that unequal services will increase in the virtual environment. Based on other evidence, however, it is equally likely that e-service providers may offer unbiased service. This paper is designed to address the following question: Do eservices provide equitable online services to the public? Thus, this paper reports on two experimental studies that examine whether online discrimination exists in services that are provided to the general public. Both studies address the same research question and apply a similar research design and methodology but differ in the type of library examined; one experiment focuses on academic librarians and the other on public librarians.

First we review the literature on e-service quality evaluation, and focus on the evaluation of virtual library reference services. Next, the methods and procedures for data collection and data analysis of the two experiments are described. Following is a 
discussion of the findings and their implications for research and practice. The limitations of this study are illustrated and future research directions are suggested.

\section{BACKGROUND}

An attempt to evaluate service equality must first identify appropriate quality dimensions; the level of service provider's performance on these quality dimensions can be then compared across different user groups. This study focuses on service equality by evaluating the quality of direct e-services provided by information professionals to diverse user groups. Evaluation of direct e-services focuses on the technologymediated interaction of the user directly with service providers and is different from the evaluation of indirect e-services that focuses, for example, on information systems and services portfolios, when the user does not interact directly with service providers. This study evaluates the equality of online mediated interactions between service providers and users of virtual reference services. For that reason both virtual reference and eservice evaluations are discussed next.

Evaluation of reference services has been the focus of much research which applied a variety of methods; these methods have focused on the types of questions asked, the accuracy of the information provided by a reference librarian, user satisfaction, librarian's behavior, and library collections (Gross \& Saxton, 2002; Saxton \& Richardson, 2002). While some researchers adapted methods from traditional (in person) reference service to evaluate virtual reference services, others recommended the development and use of new ways to evaluate these services (Hernon \& Calvert, 2005; McClure, Lankes, Gross, \& Choltco-Devlin, 2002; White, 2001). Traditional reference services evaluation was frequently done through unobtrusive methods (Saxton, 2002).

One of these unobtrusive studies, conducted by Hernon and McClure (1986), found that librarians' responses are accurate only $55 \%$ of time, and generated many replications which consistently verified similar success rates (Saxton \& Richardson, 2002). Whitlatch $(1989 ; 2001)$ emphasized that the unobtrusive method can also be used effectively for virtual reference evaluation and a number of evaluation studies of virtual reference services employed this method (Arnold \& Kaske, 2005; Carter \& Janes, 2000; Kaske \& Arnold, 2002; Shachaf \& Horowitz, 2006; Stacy-Bates, 2003; Ward, 2003). Another measure of traditional reference success rate is based on user satisfaction. Using this measure, studies repeatedly found higher levels of satisfaction than the accuracy levels might indicate, because users' evaluations are often based on librarian behavior rather than accuracy or completeness of the answer (Saxton \& Richardson, 2002). The Reference and User Services Association (RUSA) guidelines for behavioral performance of reference and information service providers (2004a) reflect the users' emphasis on behavior and specify:

In all forms of reference services, the success of the transaction is measured not only by the information conveyed, but also by the positive or negative impact of the patron/staff interaction. The positive or negative behavior of the reference staff member (as observed by the patron) becomes a significant factor in perceived success or failure. This connection has been born out in the work of researchers like Gers and Seward (1985), who found that "behaviors have a strong influence on performance", and Whitlatch (1990), who stated "Librarian courtesy, interest, and helpfulness are crucial in providing successful reference 
service. Libraries must select and retain staff who have these service orientations toward users." Matthew Saxton (2002) put the Guidelines to a statistical test, and found that they did indeed correlate highly to a successful reference transaction. (para.4).

Thus, one of the predictors of a reference transaction's success can be attributed to the interaction between the user and the librarian (Gers \& Seward, 1985; RUSA 2004a; Whitlatch, 1990). Researchers have focused attention on user - librarian interactions in traditional and virtual reference. Radford (2006), for example, focused on the interpersonal dimension of virtual reference and identified the relational dimensions that were present in chat reference transcripts.

When evaluating service success rate, researchers and practitioners utilize either a user or librarian's perspective. Each of these perspectives bears valuable results that have implications for research and practice, yet each is limited. There seems to be a strong relationship between users' perceptions of service quality and policies' formulation, implementation, and evaluation. An understanding of the quality of services from the user perspective is crucial and informative as it provides feedback to service providers and administrators. Thus, there have been several efforts to identify the quality dimensions of e-services in general, (e.g., Madu \& Madu, 2002; Parasuraman, 1985; Parasuraman, Zeithaml, \& Berry, 1988; Yang, Jun, \& Peterson, 2004) and virtual services in particular, from the user perspective (e.g., Hernon \& Calvert, 2005; O'Neill, Wright, and Fitz, 2001).

Virtual reference services, like other online services, experienced an extensive growth during the last decade, yet the quality of these online services is frequently perceived to be inferior to traditional face-to-face services (Yang, Jun, \& Peterson, 2004). Over the past three decades researchers have made efforts to uncover the most important dimensions of perceived service quality (e.g., Parasuraman, 1985); more recently, these efforts have focused on e-services quality (e.g., Yang, Jun, \& Peterson, 2004). Many of the dimensions for evaluating service quality in the face-to-face environment are as influential in the virtual environment. For example, some of the dimensions include (Parasuraman, 1985): reliability (accuracy), responsiveness (promptness and timeliness), competence (knowledge and skills), access (approachability and accessibility), courtesy (politeness, respect, and friendliness), security (freedom of risk), understanding (individual attention), communication (explanations), credibility (trustworthiness by name and company name), and tangibles (material resources). Parasuraman, Zeithaml, and Berry (1988) attempt to expand the use of traditional service models to the internet using SERVQUAL, which includes five dimensions (Madu \& Madu, 2002): reliability (dependability and accuracy of service), responsiveness (prompt services), assurance (trust and confidence - based primarily on knowledge and courtesy of employees), empathy (caring and individualized attention to users), and tangibles (appearance of physical facilities and equipment) (Parasuraman, Zeithaml, \& Berry, 1988). Parasuraman, Zeithaml, and Berry's (1988) scale for measuring consumer perceptions of service quality are probably the most widely used (Voss, 2003). These include:

"Tangible: Physical facilities, equipment, and appearance of personnel;

Reliability: Ability to perform the promised service dependably and accurately; Responsiveness: Willingness to help customers and provide 
prompt service; Assurance: Knowledge and courtesy of employees and their ability to inspire trust and confidence; and Empathy: Caring, individualized attention the firm provides its customers" (Parasuraman, Zeithaml, \& Berry, 1988, p. 23).

Yang, Jun, and Peterson (2004) identified 17 dimensions in the literature, 10 of which indicate customer service quality: responsiveness (prompt response), reliability (accurate and efficient response), competence, access (accessibility of service and contact information), personalization, courtesy, continuous improvement, communication, convenience, and control.

O'Neill, Wright, and Fitz (2001) applied the SERVQUAL dimensions to examine the quality of online services in an Australian library and focused particularly on contact, responsiveness, reliability, and tangibles. Hernon and Calvert (2005) developed a survey instrument, e-SERVQUAL for libraries, which focuses exclusively on examining library services online. They found that unlike the traditional five dimensions of SERVQUAL (tangible, reliability, responsiveness, assurance, and empathy) the most important dimensions to library users were (in order of importance) ease of use, collections, reliability, customization/ personalization, security/ privacy/ trust, support, ease of access, linkage, flexibility, and web site aesthetic. These efforts have focused on both direct and indirect e-services.

Specific guidelines for the quality of direct e-services of information professionals and librarians have been published by the International Federation of Library Associations (IFLA) digital reference guidelines (International Federation of Library Associations, 2005a), the Reference and User Services Association (RUSA) guidelines for implementing and maintaining virtual reference services (Reference and User Services Association, 2004b), and the RUSA guidelines for behavioral performance of reference and information service providers (Reference and User Services Association, 2004a). Using these guidelines for direct services and Yang, Jun, and Peterson's (2004) dimensions of e-services, this study focuses on the following three quality dimensions:

1. E-service - Responsiveness/ Timely response (Yang, Jun, \& Peterson, 2004). Virtual reference - by acknowledgement of user email questions in a timely manner, providing patrons with responses as quickly as possible, and adherence to stated turnaround policy (International Federation of Library Association, 2005a; Reference and User Services Association, 2004a).

2. E-service - Reliability (Yang, Jun, \& Peterson, 2004).

Virtual reference - by answering the query efficiently and correctly and providing a signature that contains the librarian's name or initials, title, and institution (International Federation of Library Association, 2005a).

3. E-service - Courtesy (Yang, Jun, \& Peterson, 2004).

Virtual reference - by approachability, friendliness, politeness, and professional courtesy (International Federation of Library Association, 2005a; Reference and User Services Association, 2004a; Reference and User Services Association, 2004b).

This study focuses on the equality of e-service among user groups as evaluated on these three quality dimensions. Theses three quality dimensions are central to the professional guidelines and are easily measurable for our research purposes. Service equality is defined as an equal level of quality of services provided to all users, without 
discrimination on the grounds of race or gender. Overall service quality is reduced when some users receive a lower level of service as measured by the three dimensions of quality evaluated in this study. Thus we examined the following hypotheses:

$\mathrm{H} 1$. All user groups will receive an equally timely response.

$\mathrm{H} 2$. All user groups will receive an equal level of reliable service.

H3. All user groups will receive an equal level of courtesy.

A timely response is sent to the user within the response time stated on the library policies. Specifically, the amount of time it takes for an answer to be sent to the user should not differ significantly in hours or days among different user groups. A reliable response has two components (Tables 2 and 3 ): a complete (answers all parts of the request) and accurate response (provides accurate information), and a librarian's signature and contact information. A courteous response includes greetings and thank you; all users should be treated with an equal level of courtesy.

\section{METHOD}

Two experiments using scenarios of information needs were conducted among eservices that are provided by libraries in North America. One experiment involved academic libraries and the other experiment involved public libraries. The experimental feature of the study is that the requests differed only in the implicit ethnicity of the user involved in the incidents, which was indicated by the users' names. The academic libraries experiment involved six versions of each request. Each version of the request represented one ethnic group: African American, Hispanic, Asian, and Caucasian, or one religious group identification: Christian (Caucasian), Muslim (Arab), and Jewish. The public libraries experiment involved four versions of each request. Each version of the request represented one ethnic group and one gender: female African-American, male African-American, female Caucasian, and male Caucasian. The targeted e-service received a version of the same request but with a different user name (indicating a different ethnic, gender, or religious affiliation). In this way, it was possible to determine whether e-services provide equivalent service to different groups when salience of diversity (e.g., ethnic group) is not an obvious factor and when all other factors are constant. This method is particularly important when attitude and behavior variability are measured on sensitive variables, such as diversity. To avoid social ramifications, people may monitor their discriminatory behavior more closely if they believe the study is related to race (Bushman \& Bonacci, 2004).

The use of names perceived to be of a particular ethnicity is a common method to examine possible bias (e.g., Bertrand \& Mullainathan, 2004; Figlio, 2005). The names used to represent gender and ethnic groups in the public libraries study are: Latoya Jones (female African-American), Tyrone Jackson (male African-American), Emily Baker (female Caucasian), and Todd Kelly (male Caucasian) (Bertrand \& Mullainathan, 2004).

In their study, Bertrand and Mullainathan examined birth certificates from Massachusetts from 1974-1979 to create lists of names most frequently given to African-American and Caucasian infants. They developed a list of 36 names, nine names for each of the four ethnic groups by gender: female Caucasians, female African-Americans, male Caucasians, and male African-Americans. These names were tested and confirmed in a pilot study before being used to examine possible bias in 
selecting and interviewing job applicants in two cities. Due to the rigorous verification of the names, the authors were confident that most people would assume AfricanAmerican ethnicity for certain names and Caucasian ethnicity for other names. Among the names used in this study were Latoya, Tyrone, Emily, and Todd; we chose these names for the public libraries study as representative of their respective gender and ethnicities. Furthermore, since we portrayed our questioners as adults, the age range of names developed from Bertrand and Mullainathan's study (born in 1974-1979) was appropriate. Since our use of these four names was based upon previous research, we were confident that the assumed gender and ethnicity would be identified by most recipients.

The names used to represent ethnic groups in the academic libraries study are: Latoya Johnson (African-American), Rosa Manuz (Hispanic), Chang Su Asian/Chinese), and Mary Anderson (Caucasian). Representing religious group affiliation the names used were: Mary Anderson (Christian), Ahmed Ibrahim (Muslim), and Moshe Cohen (Jewish). These names were selected from online lists of common baby names.

\section{DATA COLLECTION Study 1 - Academic Libraries}

Using The Carnegie Classification of Institutions of Higher Education (The Carnegie Foundation for the Advancement of Teaching, 2000) all doctoral/research universitiesextensive and doctoral/research universities-intensive university libraries were invited by an e-mail sent to the head of the reference department to participate in a study ${ }^{1}$. Two batches of requests were sent, (during the summer of 2005 to 123 ARL libraries and during the winter of 2005-2006 to an additional 218 doctoral/research universities extensive and intensive), and 54 libraries agreed to take part in the study (for a participation rate of $16 \%$ ).

A total of 324 queries were sent during the 2005-2006 academic year. In the fall of 2005138 e-mail reference requests were sent to 23 libraries and during the spring of 2006186 e-mail reference requests were sent to 31 libraries; each library received one request per week during six consecutive weeks (either during the fall semester or during the spring semester). Each library received five or six different types of requests using six different names and six different e-mail accounts. During the fall semester, every week 23 messages were sent from one e-mail account (one user), one per library, five of each type of question. In order to account for the effect of the rhythm of the semester on the type of question or user names, during the spring semester a different pattern of ending requests was implemented. Every week 31 messages of the same type of question were sent from six e-mail accounts, using six user names, one request per library.

Five reference queries were used in this study in the fall semester and six reference queries were used in the spring semester (of which five were the same queries used in the fall). These are the queries that were sent:

\footnotetext{
${ }^{1}$ Obtaining the permission of the head of the department to conduct this research was required by our institution's Human Subjects Committee. By obtaining permission from the department head, rather than the reference librarians themselves, we attempted to preserve the unobtrusive nature of the study.
} 
1. Dissertation query: Can you tell me the title of [name]'s dissertation? [She/He] finished [his/her] degree at [institution name] in [year]. Do you have it in your library? How can I obtain a copy of this dissertation?

2. Sports team query: How did [sports team name] become the name for [institution name]'s sports teams? Can you refer me to a book or article that discusses it?

3. Population query: Could you tell me the population of [institution's city name] in 1963 and 1993?

4. Subject query: Could you help me find information about [special collection topic]? Can you send me copies of articles on this topic?

5. Article query: Can you send me by e-mail a copy of the article "Free Indirect Discourse and Narrative Authority in Emma" by D.P. Gunn?

6. Could you please send me a pdf copy of pp. 66-69 (ch.V) from Strunk and

White's The Elements of Style? [used during the spring semester only] Questions 1, 2 and 3, followed Stacy-Bates' examples (2003, p. 61), which according to her findings are expected to be answered by more than $90 \%$ of the ARL libraries. These requests are likely to be answered by ARL libraries when asked by unaffiliated users because some institutions limit the scope of services that they provide to unaffiliated users, but still answer requests for information specific to that institution. Following these findings, it was expected that most of the participant libraries will respond to unaffiliated users on these three queries. However, it was also expected that academic libraries will not be inclined to answer queries 4-6 when made by unaffiliated users. When the virtual reference service policies of the participant libraries were examined it was found that most of them limit their virtual reference services to unaffiliated users. These policies specify that the library will answer unaffiliated users' requests only when they submit questions that are specific to the library or university. Assuming that reference librarians are aware of the policies for unaffiliated users it was expected that they will not provide support to unaffiliated users with their topical requests, such as question 4. Finally, it was assumed that reference librarians will comply with intellectual property and copyrights laws and will follow the terms of use of electronic journals and databases. Therefore, it was expected that the fifth and sixth requests will be rejected by the participant libraries.

Before the questions were sent, information about each institution was collected to formulate the questions that ask about information unique to the institution. Each institution file included (1) details of a dissertation that was awarded by the institution in 1964 (or the earliest date thereafter) which was identified using Dissertation Abstract, (2) sports team's name as identified from a search on the parent institution website, (3) topics of special collections for the subject query, (4) policies about service restrictions for unaffiliated users and response time. In addition, a full text article that was available via EBSCO Academic Search Premier was selected for the fifth question. It was assumed that any academic library would have access to the full-text of this article, but that due to licensing restriction librarians would be less likely to send the full text of the article.

The counterbalanced method was used to avoid variables confounding. The technique in counterbalancing is to make sure that each user name appears in each position an equal number of times. Each user sent the same number of messages, each 
library received only one request from each user, and each library received a specific type of request only once. Each week, a different question was received at the reference service of an institution from a different user. ${ }^{2}$ Each of the repeated requests, which were sent during the sixth week in the fall semester, was different from the first request an institution received during the first week of data collection. These requests had a different article title, dissertation title, and years but followed exactly the same text.

During the spring semester the sixth question was a different question (Q. 6); all the libraries were asked for the full text of a book chapter.

\section{Study 2 - Public Libraries}

During winter and spring 2006, 386 public libraries were recruited for participation using lib-web-cats (Breeding, 2006), a publicly available directory of libraries throughout the world. ${ }^{3}$ Using this directory, a list of public libraries in the United States was created. The first 20 states in the alphabetic list of states were examined and public libraries that provided virtual reference services to their users were identified. For each town, county, or city the main library was selected so the data will represent independent cases. Library consortia, statewide virtual reference services, and cooperative reference services, in which many institutions participate, were not included in the study, since some library consortia involve multi-type and academic libraries, and this study was limited to public libraries. Only libraries that provided a mailto link or a web form specifically for reference questions that users can complete were included in the sample list (Stacy-Bates, 2003). Surprisingly, only $7.8 \%$ of the libraries on the libweb-cat directory provided links to this service. ${ }^{4}$ The print version of American Library Directory

\footnotetext{
${ }^{2}$ An example of the chronological order, user name, and type of questions a particular institution received as part of this study during the fall semester is given below.

Week 1: Mary Anderson - Could you tell me the population of [city name] in 1963 and 1993?

Week 2: Moshe Cohen - Could you help me find information about [special collection topic]? Can you send me copies of articles on this topic?

Week 3: Ahmed Ibrahim - Can you send me by e-mail a copy of the article "Free Indirect Discourse and Narrative Authority in Emma" by D.P. Gunn?

Week 4: Latoya Johnson - Can you tell me the title of [author]'s dissertation? He finished his degree at [institution name] in 1964. Do you have it in your library? How can I obtain a copy of this dissertation?

Week 5: Rosa Manuz - How did [sports team name] become the name for [institution name]'s sports teams? Can you refer me to a book or article that discusses it?

Week 6: Chang Su - Repeated question

${ }^{3}$ Before conducting this study, several directories of public libraries were evaluated, and lib-web-cats and the online version of American Library Directory were the two sites likely to contain the most complete, accurate online directory of public libraries. One state, Connecticut, was randomly chosen and the numbers

of functioning links to public libraries provided by each directory were compared. Lib-web-cats provided a list of 239 public libraries in Connecticut, of which $36.4 \%$ had functioning links for email or web-form for reference services. American Library Directory (online) provided 235 public libraries in Connecticut, of which $61.7 \%$ had functioning links for email or web-form for reference services. However, access to the online version of the American Library Directory was restricted to subscribed institutions and we utilized the free lib-web-cats directory.

${ }^{4}$ This number may be lower than expected given previous reports in the literature (Coffman, 2003), since this study did not include statewide virtual reference services, which are often provided by a state library, a private company, a library school, or some other combination which did not fit the parameters of this
} 
(2006) was utilized to verify names, titles, and email addresses of public library directors; the directors were then emailed recruitment letters and a link to an informed consent form. Library directors were recruited for their consent to attempt unobtrusive study of reference service. After recruitment, eighty-eight library directors agreed to take part in the study for a participation rate of $22.80 \%$. The participating libraries are located in all four of the regions defined by the U.S. Census Bureau. Approximately $23.9 \%$ of the libraries are in the South, $44.3 \%$ are in the Midwest, $13.7 \%$ are in the Northeast and $18.2 \%$ are in the West.

In the spring of 2006, email reference requests were sent to 88 libraries; each eservice received one request per week during four consecutive weeks. A total of 352 email queries were sent. An example of the chronological order, user name, and type of question received by a particular institution is given in Table 1.

Insert Table 1 approximately here

Four reference queries were used which represented questions likely to be directed to reference departments of public libraries. The requests were:

1. Town population: What was the population of [town in which library is located] in 2000 ?

2. Known item: Does your library have Romeo and Juliet? [or Does your library have Harry Potter and the Half-Blood Prince?]

3. Topical question: Can you help me find some resources about growing and taking care of rosebushes?

4. Ready reference: What is the average temperature in May in London?

Before the questions were sent, information about each library was collected so the accuracy of responses could be determined. Information about town populations was collected using the Population Finder feature of the U.S. Census (2006) and London temperature averages were drawn from the BBC Weather Service (British Broadcasting Corporation, 2006). Each library's online catalog was used to determine if they had Romeo and Juliet in their collection; for libraries whose online catalog was inaccessible, we asked them for a recent bestseller, Harry Potter and the Half-Blood Prince. It was assumed that most libraries would have Romeo and Juliet and the latest Harry Potter book (which was borne out in our data collection).

\section{DATA ANALYSIS}

All 676 responses to the queries were uploaded into Nvivo 2.0 (324 queries from the academic libraries study and 352 queries from the public libraries study). Nvivo is software that supports qualitative analysis. Using Nvivo facilitates content analysis and the search for frequencies and co-occurrences of codes and attributes. Further, Nvivo matrix capabilities facilitate the identification of patterns among categories and also between categories and attributes. Using SPSS 13.0, one-way ANOVA and cross tabulations were conducted to identify differences among users groups. Content analysis of virtual reference transcripts was applied by other researchers to evaluate the

study. Many libraries whose online reference services did not meet this study's criteria did provide links to these other services. 
quality of the service, the types of questions, and the interpersonal communication between the librarians and the users (Pomerantz, 2005; Radford, 2006). In order to conduct content analysis of the reference transaction a coding scheme was developed, based on the Reference and User Services Association (RUSA) behavioral guidelines for general and remote reference service (incorporating guidelines for in person reference service where applicable to the online context) and the International Federation of Library Associations (IFLA) guidelines for practitioners of digital reference (International Federation of Library Associations, 2005a; Reference and User Services Association, 2004a). Table 2 presents the coding scheme used to code the transactions in both studies. In addition, each transaction was assigned values according to attributes, which describe the user name, institution code, request type, and response time. Then each transaction was classified according to the attributes and categories. After all the transactions were coded by one coder $10 \%$ of the data was coded by a second coder to evaluate the level of inter-coder reliability. The coding was followed by a discussion among the coders that clarified codes and modified the coding scheme. Coding by the two coders continued until an acceptable level of agreement between the two coders was reached for each set of codes. The final result of the inter-coder reliability was Cohen's Kappa $=.787$ for the academic libraries study and Cohen's Kappa $=1$ for the public libraries study.

Insert Table 2 approximately here

\section{RESULTS}

\section{Study 1 - Academic Libraries}

The content analysis of the 324 e-mail transactions revealed differences and similarities in the quality of service that virtual reference librarians provide to various users groups. Table 3 summarizes the frequencies of codes by user group. Each of the ethnic or religious groups is represented by a shorter version of the names using the first name of the user (for example, Mary instead of Mary Anderson).

Insert Table 3 approximately here

\section{Timely response}

As can be seen in Table 4 the average amount of time it took to respond to users' requests differs among users, yet, these differences are not statistically significant. A one-way analysis of variance was conducted to evaluate the relationship between the response time and users. The ANOVA was not significant, $F(5,318)=1.969, p=.083$. Thus we conclude that there are no significant differences among user groups in terms of ethnicity and religion.

Insert Table 4 approximately here

$\mathrm{H} 1$ was supported; all users receive the same level of service in terms of timeliness of the response. 


\section{Reliability}

An indication of reliability of e-services is evaluated based on the provision of contact information and name of the service provider with departmental affiliation. These are most likely defined in e-services policies and are not supposed to vary among user groups. The frequencies of inclusion of names, department affiliation, or contact information are described in Table 3 as part of the reliability indicators.

Two way contingency tables analyses were conducted to evaluate whether the inclusion of the librarian's name, department name, or contact information was different among users. Librarian's name and users were found not to be significantly related, Pearson $\mid 2(5, N=324)=8.348, p=.138$, Cramer's $V=.158$. Department name and users were found not to be significantly related, Pearson $2(5, N=324)=2.156, p=$ .827 , Cramer's $V=.082$. Contact information and users were found not to be significantly related, Pearson $\mid 2(5, N=324)=6.254, p=.282$, Cramer's $V=.139$. There are no significant differences among different user groups.

A second important indicator of service reliability is the accuracy and completeness of the responses that were received by the different user groups. Accuracy was evaluated for the answers to the dissertation and population questions only, using either Dissertation Abstracts for the dissertation question and the source provided by the librarian or the U.S. Census for the population question. Completeness was evaluated based on whether all parts of a multi-part question had been answered, or whether the specific task requested had been preformed. Two way contingency tables analyses were conducted to evaluate whether the completeness of the responses was different among users, and whether the accuracy of the responses was different among users. Completeness and users were found not to be significantly related, Pearson $2(5, \mathrm{~N}=$ $324)=1.533, p=.909$, Cramer's $V=.076$. Accuracy and users were found not to be significantly related, Pearson $2(5, N=324)=3.356, p=.645$, Cramer's $V=.102$. All users were treated equally in terms of completeness and accuracy of the responses.

$\mathrm{H} 2$ was supported; all users receive the same level of service in terms of reliability.

\section{Courtesy}

Another indication of the quality of service is the way the e-service provider addresses the user. The use of honorifics and greetings indicate a higher level of politeness and the use of first name indicates a higher level of friendliness (in the United States). Similarly, including "thank you for using the service" in the message is another indication of courtesy. The frequencies of greetings, thank you, honorifics, and first name in the responses for each user group are described in Table 3.

A two way contingency table analysis was conducted to evaluate whether the use of first name in the response was different among users. Use of first name and users were found to be significantly related, Pearson $\mid 2(5, N=324)=13.831, p=.017$, Cramer's V = .207. Follow-up pairwise comparisons were made to evaluate the differences among users. The Tukey's HSD method was used to control for type I error at the .05 level across all six comparisons. The significant pairwise differences were between Chang Su and all other users.

A two way contingency table analysis was conducted to evaluate whether the use 
of hello in the response was different among users. Use of hello and users were found not to be significantly related, Pearson $\mid 2(5, \mathrm{~N}=324)=3.956, \mathrm{p}=.556$, Cramer's $\mathrm{V}=$ .11. The frequencies for full name and honorifics per cell were less than five for some users; cross-tabulation in these cases could not be meaningful and therefore was not conducted. It should be emphasized that the frequencies show that Mary is addressed with honorific twice as many times than Moshe, Latoya, Ahmed, or Chang. Also, Chang $\mathrm{Su}$ is never addressed with an honorific and is addressed much less frequently by first name than other users, but instead is addressed much more by full name. Traditionally, Chinese names place the surname before the given name, which may make it more difficult to distinguish between the two. For that reason it is possible that librarians are confused about Chinese first names and address Chang Su by full name in order to cope with this confusion. Thus the ways in which librarians address different users vary, but this variation is not statistically significant and does not indicate inequality in the level of service provided.

H3 was supported; all users receive the same level of service in terms of courtesy.

\section{Study 2 - Public Libraries}

The content analysis of the 352 e-mail transactions revealed differences and similarities in the quality of service that virtual reference librarians in public libraries provide to various users groups. Three hundred fifty two queries were sent to 88 libraries and some libraries sent multiple messages in response to the queries; some of these were automatic responses. Ninety four $(26.7 \%)$ queries received no response (Latoya - 23 queries; Emily - 23 queries; Tyrone -23 queries; and Todd -25 queries). Table 5 summarizes the frequencies of codes by users.

Insert Table 5 approximately here

\section{Timely response}

As can be seen in Table 4 the average amount of time it took to respond to users' requests differs among users. It is evident that Tyrone is getting the quickest reply and the best level of service. It is also obvious that Todd is getting the worst level of service as it takes on average much longer for librarians to reply to his requests.

A one-way analysis of variance was conducted to evaluate the relationship between the response time and users. The ANOVA was not significant, $F(3,297)=1.18, p=$ .318. Thus we conclude that there are no significant differences among user groups.

$\mathrm{H} 1$ was supported; all users receive the same level of service in terms of timeliness of response.

\section{Reliability}

Accuracy and completeness of responses were evaluated for each of the users to indicate level of e-service reliability. Table 5 provides frequencies for complete, partial and accurate responses for each question type. Complete responses included an answer to the question (such as the population of the town) as well as specific reference information. Partial responses included either the information sought, or reference 
information, but not both. Accurate answers were those that matched the data located via authoritative sources, such as the U.S. Census for population figures. A two-way contingency table analysis was conducted to evaluate whether response accuracy was different among the four users. As can be seen in Table 6, accuracy, complete, or partial responses were found to not be significantly related to the four users.

Completeness and users were found not to be significantly related, Pearson 2 ( $3, N=$ $352)=2.769, p=.429$, Cramer's $V=.089$. Accuracy and users were found not to be significantly related, Pearson $2(3, N=352)=1.46, p=.692$, Cramer's $V=.064$. Complete and accurate answers were found not to be significantly related to ethnicity or gender (Table 6). A two-way contingency table analysis was conducted to evaluate whether complete, partial, and accurate responses differed based on gender or ethnicity. Table 7 provides results of the cross tabulations by gender and ethnicity for reliability. Completeness and gender were found not to be significantly related, Pearson $2(1, N=352)=.014, p=.907$, Cramer's $V=.006$. Accuracy and gender were found not to be significantly related, Pearson $2(1, N=352)=.250, p=.617$, Cramer's $V=$ .027 . Completeness and ethnicity were found not to be significantly related, Pearson 12 $(1, N=352)=.345, p=.557$, Cramer's $V=.032$. Accuracy and ethnicity were found not to be significantly related, Pearson $\mid 2(1, N=352)=.118, p=.410$, Cramer's $V=.019$. Complete and accurate answers were found not to be significantly related to ethnicity, or gender (Table 7). No differences were found based on users, ethnicity, or gender. All users were treated equally in terms of accuracy and completeness of the responses they received.

Another indication of reliability of e-services is evaluated based on the provision of the name of the service provider, departmental affiliation, and contact information. The frequencies of inclusion of names, job title, department affiliation, library name, and contact information are described in Table 5. A two-way contingency table analysis was conducted to evaluate whether inclusion of names, job title, department affiliation, library name, and contact information was different among the four users. As can be seen in Table 6, inclusion of names, job title, department affiliation, library name, or contact information were found to not be significantly related to the four users. A twoway contingency table analysis was conducted to evaluate whether inclusion of names, job title, department affiliation, library name, and contact information was different by gender or ethnicity. As can be seen in Table 7, inclusion of names, job title, department affiliation, library name, or contact information were found to not be significantly related to gender or ethnicity.

\section{Insert Tables 6 and 7 approximately here}

$\mathrm{H} 2$ was supported; all users receive the same level of service in terms of reliability.

\section{Courtesy}

The ways the user is addressed by librarians is another indication of the quality of service. The use of honorifics and greetings indicate a higher level of politeness and the use of first name indicates a higher level of friendliness (in the United States). Similarly, 
including "thank you for using the service" in the message is another indication of quality. The frequencies of greetings, honorifics, first name, full name, last name and thank you (greetings and closure) in the responses for each of the four users are described in Table 5. A two-way contingency table analysis was conducted to evaluate whether librarians' courtesy was different among the four users. As can be seen in Table 6 the inclusions of greetings, honorifics, and thank you in the responses for each of the four users were found to not be significantly related to the four users. Use of honorific and users were found not to be significantly related, Pearson $2(3, N=352)=$ $4.5, p=.212$, Cramer's $V=.113$. Thank you and users were found not to be significantly related, Pearson $2(3, N=352)=.787, p=.852$, Cramer's V =.047. Greetings (Hello) and users were found not to be significantly related, Pearson $\mid 2(3, N=352)=1.616, p$ $=.656$, Cramer's $V=.068$. Courtesy measures were found not to be significantly related to ethnicity, or gender (Table 7).

A two-way contingency table analysis was conducted to evaluate whether level of courtesy was different based on gender or ethnicity. Table 7 provides results of the cross tabulations by gender and ethnicity for courtesy. The use of honorific and gender were found not to be significantly related, Pearson $\mid 2(1, N=352)=.325, p=.568$, Cramer's $V=.031$. Thank you and gender were found not to be significantly related, Pearson $\mid 2(1, N=352)=.354, p=.552$, Cramer's $V=.033$. Greetings (Hello) and gender were found not to be significantly related, Pearson $2(1, N=352)=.296, p=$ .586 , Cramer's $28 \mathrm{~V}=.030$. The use of honorific and ethnicity were found not to be significantly related, Pearson $22(1, N=352)=1.302, p=.254$, Cramer's $V=.063$. Thank you and ethnicity were found not to be significantly related, Pearson $\mid 2(1, N=$ $352)=.354, p=.552$, Cramer's $V=.033$. Greetings (Hello) and ethnicity were found not to be significantly related, Pearson $2(1, N=352)=.000, p=1$, Cramer's $V=.000$. Courtesy measures were found not to be significantly related to ethnicity or gender (Table 7). No statistically significant differences were found based on user ethnicity or gender. All users were treated equally in terms of courteousness of the responses they received.

H3 was supported; all users received the same level of service in terms of courtesy.

\section{DISCUSSION AND CONCLUSIONS}

Our study found that differences in quality of e-services in libraries among user groups exist but that these are not statistically significant. In other words, the study provides evidence for equality of virtual services to diverse user groups on three quality measures: timely response, reliability, and courtesy. However, discrimination on ethnic, race, gender, age, or religious grounds has been observed and reported extensively in the literature. For example, Cesare (1996) reviewed studies that focused attention on discriminatory behaviors in employment interviews. Riesch and Kleiner (2005) reported about recent cases of service discrimination on the grounds of race and disabilities in restaurants. These discriminatory acts are not unique to restaurants but have been largely documented in public accommodations (Feagin, 1991). Studies on library discrimination are scarce and are limited mostly to studies of gender and race bias in employee recruitment and promotion (e.g., Curry, 1994). Shachaf and Horowitz (2006) report findings of service discrimination by librarians in ARL libraries against Arabs and African-Americans and call for more research and additional training for librarians to 
avoid inequality in access to information. Yet, the findings of our study, unlike these earlier reports, indicate equality of services by gender and ethnicity in both academic libraries and public libraries. These results are discussed in light of three possible explanations: 1. that the provision of equitable virtual reference service is indicative of librarians' adherence to their ethical values; 2 . that the findings indicate the potential of the online environment to reduce subjective bias online; and 3 . that the findings of the current study are a result of its limitations.

\section{Equitable service as an indication of librarians' ethical values}

Section 201(a) of the Civil Rights Act of 1964 (42 USC $\S 2000 a(a), 1964)$ states that "all persons shall be entitled to the full and equal enjoyment of the goods, services, facilities, privileges, advantages, and accommodations of any place of public accommodation.... without discrimination or segregation on the ground of race, color, religion, or national origin." Along the same lines, a core norm of the library profession is the provision of "high level of service to all library users through... accurate, unbiased, and courteous responses to all requests" (ALA, 1995). This language is also echoed in the Core Values statement of the International Federation of Library Associations (2005b). Further, free and equal access is a core ethical principle found in all library ethical values typologies (Froehlich, 1997; Koehler \& Pemberton, 2000; Gorman, 2000; Mason, 1986; Shachaf, 2005a; Smith, 1997; Rubin \& Froehlich, 1996). Equal access is one of the few core values of librarianship that is shared across the globe (Shachaf, 2005a). It is possible that these core values are learned as part of becoming a professional librarian because when Dole and Hurych (2001) asked library science students at one university to rank the three most important values of the profession, $89 \%$ of students included "service to clientele" and $32 \%$ included "equitable access" in this top tier (p. 46). Librarians, like other public sector employees, value equitable services highly (Houston, 2000). Therefore it is possible that the provision of equitable services to library users by librarians is a direct result of their adherence to their core professional values and their professional ethical code.

While this explanation seems reasonable, such an argument cannot be made based only on one study, especially since service discrimination is an understudied research domain in librarianship. Because of the lack of studies that focus attention on service equality, it is unclear if librarians provide equitable service to users who visit the library in person. It is possible that librarians, when providing traditional (in-person) library services, do not discriminate against users on the grounds of race or gender, but it is equally possible that they do. Future studies should evaluate service equitability that librarians provide at the library. Similarly, it is unclear if service equality is the norm on all library services (e.g., circulation, in person consultation, interlibrary loan requests, and so on) or that only reference librarians are unbiased. Future research should focus on these types of service, and examine service equality in providing other library services, both online and in-person.

Furthermore, to make an argument that the findings of this study reflect librarians' adherence to their core ethics, additional research should focus on librarians' ethical behavior overall. For example, future studies could examine the extent of librarians' awareness of and adherence to their professional code of ethics. If librarians are aware of their code of ethics and adhere to it on other core values as well, it may be possible 
to make a sound argument that the findings of this study reflect librarians' core values. Finally, librarians' adherence to their ethical norms should be compared to other service providers. These studies should evaluate equality of service using the same quality dimensions across sectors. Based on these kinds of studies the explanation that librarians adhere to their ethical values can be justified and accepted.

In sum, while it is tempting to explain the findings of this study as a result of the ethics of librarians, such an argument would be strengthened if other studies reported empirical findings that support this explanation.

\section{The potential of the online environment to reduce subjective bias}

Another possible explanation of the findings focuses on the medium of communication that is utilized by virtual reference service. The idea that the virtual environment bears potential for equalization was suggested and documented in the context of group decision making (e.g., Daily \& Steiner, 1998; Daily, Whatley, Ash, \& Steiner, 1996; Shachaf, 2005b; Sproull \& Keisler, 1986). When communication is mediated by computers, social presence is reduced (Sproull \& Keisler, 1986). Interactions are more impersonal and task-oriented because of the lack of social cues, lack of context, and lack of non-verbal behavior. Further, decreasing social cues have a democratizing effect on communication resulting in status equalization. The relative absence of social cues means greater equality of services in the virtual environment. Therefore, online discrimination is less common due to the ability of potential targets to eliminate social and group identification cues and even to remain anonymous; the relative absence of social cues means greater equality of services in the virtual environment (Glaser \& Kahn, 2005). While researchers suggested the potential of equalization in computermediated communication (Sproull \& Keisler, 1986), this potential mitigation has rarely been examined in service organizations.

This explanation stresses the potential of virtual reference to overcome barriers associated with stereotypes, prejudices, and the potential it bears to lessen the amount of discriminatory behaviors. However, this argument about the potential of the virtual environment to eliminate social cues and increase equality needs to be further supported by empirical findings. At present the only two other studies that focused on online discrimination challenge this argument and provide data to contradict it (Bushman \& Bonacci, 2005; Shachaf \& Horowitz, 2006). Thus the explanation that the medium allows for less bias should be supported or rejected by future research. In order to accept such an explanation, future research should manipulate the medium through which the service is provided (e.g., face-to-face, phone, email, chat). If the findings of such studies show a reduction in service discrimination, the extent of reduction in online subjective bias compared to traditional setting should be examined as well. If on the other hand the findings indicate a similar level of discrimination or even higher levels of discrimination online, it bears major implications for training, performance evaluation, and service quality assessments.

In sum, while it is tempting to explain the findings of this study as a result of the medium, such an argument needs to be supported by future research manipulating the medium of service provision.

\section{Limitations}


The third possible explanation of the findings of this study lies in the limitations of the study. These limitations should be evaluated in light of the existing research in this area and the motivation to conduct this study. The current study was motivated by the pilot study (Shachaf \& Horowitz, 2006), which indicated possible discrimination against Arabs and African Americans. However, due to the small sample size, statistical significance could not be determined. In addition, the pilot study did not control for possible interaction effects between gender and ethnicity. The current study involves a much larger sample: instead of 23 libraries that participated in the pilot study this study involved 142 libraries, 54 academic libraries and 88 public libraries; moreover, 676 reference transactions were analyzed in this study compared to 138 transactions that were used in the previous study. The second part of this study, focused on public libraries, was specifically designed to manipulate both gender and ethnicity. With a 2X2 factorial design, we tested for and found no significant main effect of gender or ethnicity and no significant interaction effect of gender by ethnicity. The differences between the pilot study and the current study are described in Table 8.

Insert Table 8 approximately here.

While we corrected these weaknesses of the pilot study, other limitations remain: 1) the limited scope of the quality measures; and 2) ethical consideration regarding human subjects and the threat it bears on the unobtrusiveness of this study. First, this study focused on equality of service using only three measures: timely response, courtesy, and reliability. Other variables are involved in the reference encounter which may reveal different levels of service to different user groups. It is possible for example, that different user groups exhibit different information needs and that librarians may discriminate more when certain type of questions are involved. Further, it is possible that diverse user groups have different expectations of the service provider (i.e., the reference librarian), and that their level of satisfaction would vary accordingly. It is also possible that in real life transactions sent by users from different groups will differ in the writing style, frequencies of typos, and grammar; these variations in the questions may evoke different reactions in the librarians, leading to differential levels of service.

Second, the possibility that the librarians who answered the requests were aware of the study and therefore behaved in a less discriminatory manner is another limitation of this study. The human subjects committee required the researchers to gain informed consent prior to data collection from each of the participating institutions. While the time spanned from the recruitment and data collection was long enough, and the requests were sent while using fake names and fake email accounts, there is a chance that the librarians were more conscious of their behavior and corrected for any discriminatory tendencies.

Furthermore, it is possible that our sample of libraries is biased due to the request to collect informed consent. It is possible that the libraries who agreed to participate represent institutions who prioritize equality or those that are more confident in their service equality. We conclude that the findings of this study may be an outlier that resulted from the limitations of the methodology and call for future research to support or contradict our findings. 
In sum, the findings of this study can be explained in three ways: that they are reflective of the ethical behaviors of librarians, that they are reflective of the potential of the virtual environment to lessen subjective bias, and that these results are due to the limitations of the study. Any of the three explanations would require future research to provide additional support. The findings of this study open a wide door for future research and in doing so the study provides a significant contribution to the research of librarians' ethics, research about virtual reference (and e-services), and research on online subjective bias.

Do virtual reference librarians provide equal quality of service to diverse user groups? Based on our findings we can tentatively answer "yes," since no significant differences based on race or gender were found in the quality of e-services that libraries provide to the public. The quality of service to all user groups was equal in terms of courtesy, reliability, and timely response. We conclude that the virtual environment has the potential to enable unbiased services to all users.

\section{REFERENCES}

American Library Association. (1995). Code of Ethics of the American Library Association. Retrieved May 31, 2006 from http://www.ala.org/ala/oif/ statementspols/codeofethics/codeethics.htm

American Library Directory. (2005). American Library Directory Online. Chicago: American Library Association.

Arnold, J., \& Kaske, N. (2005). Evaluating the quality of a chat service. Libraries and the Academy, 5(2), 177-193.

Bertrand, M., \& Mullainathan, S. (2004). Are Emily and Greg more employable than Lakisha and Jamal? A field experiment on labor market discrimination. The American Economic Review, 94(4), 991-1013.

Breeding, M. (2006). Lib-web-cat: A directory of libraries throughout the world. Retrieved June 5, 2006 from http://www.librarytechnology.org/libwebcats/ British Broadcasting Corporation. (2006). BBC Weather. Retrieved June 5, 2006, from http://www.bbc.co.uk/weather/world/city_guides/results.shtml?tt=TT003790

Bushman, B. J., \& Bonacci, A. M. (2004). You've got mail: Using e-mail to examine the effect of prejudiced attitudes on discrimination against Arabs. Journal of Experimental Social Psychology, 40(6), 753-759.

The Carnegie Foundation for the Advancement of Teaching (2000). The Carnegie classification of institutions of higher education. Retrieved May 22, 2006 from: http://www.carnegiefoundation.org/classifications/

Carter, D. S., \& Janes, J. (2000). Unobtrusive data analysis of digital reference questions and service at the Internet Public Library: An exploratory study. Library Trends, 49(2), 251-265.

Cesare, S.J. (1996). Subjective judgment and the selection interview: A methodological review. Public Personnel Management, 25(3), 291-305.

Civil Rights Act of 1964 § 201, 42 USC, § 2000(a) (1964).

Coffman, S. (2003). Going live: Starting and running a virtual reference service. American Library Association: Chicago.

Crosby, F., Bromley, S., \& Saxe, L. (1980). Recent unobtrusive studies of Black and White discrimination and prejudice: A literature review. Psychological Bulletin, 
87, 546-563.

Curry, D.A. (1994). Your worries ain't like mine: African American librarians and the pervasiveness of racism, prejudice and discrimination in academe. The Reference Librarian, 45/46, 299-311.

Daily, B.F., \& Steiner, R.L. (1998). The influence of group decision support systems on contribution and commitment levels in multicultural and culturally homogeneous decision-making groups. Computers in Human Behavior, 14(1), 147-162.

Daily, B., Whatley, A., Ash, S. R., \& Steiner, R.L. (1996). The effects of a group decision support system on culturally diverse and culturally homogeneous group decision making. Information \& Management, 30, 281-289.

Dole, W.V., \& Hurych, J.M. (2001). Values for librarians in the information age. Journal of Information Ethics, 10(2), 38-50.

Douglas, K. M., \& McGarty, C. (2001). Identifiability and self-presentation: Computermediated, communication and intergroup interaction. British Journal of Social Psychology, 40, 3, 399-416.

Feagin, J. (1991). The continuing significance of race: Antiblack discrimination in public places. American Sociological Review, 1, 101-116.

Figlio, D. N. (2005). Names, expectations and the Black-White test score gap. NBER Working Paper No. W11195. Retrieved June 7, 2006 from: http://ssrn.com/ abstract $=684721$

Froehlich, T. (1997). Survey and analysis of the major ethical and legal issues facing library and information services. Munich, Germany: K.G. Saur.

Gers, R., \& Seward, L.J. (1985). Improving reference service: Results of a state-wide survey. Library Journal, 110(18), 32-35.

Glaser, J., \& Kahn, K. B. (2005). Prejudice and discrimination and the internet. In Y.

Amichai-Hamburger (Ed.). The social psychology of the internet. Oxford, UK: Oxford University Press.

Gorman, M (2000). Our enduring values: Librarianship in the 21st century. Chicago, IL: American Library Association.

Gross, M., \& Saxton, M. L. (2002). Integrating the imposed query into the evaluation of reference service: A dichotomous analysis of user ratings. Library \& Information Science Research, 24, 251-263.

Hernon, P., \& Calvert, P. (2005). E-service quality in libraries: Exploring its feature and dimensions. Library \& Information Science Research, 27, 377-404.

Hernon, P., \& McClure, C. R. (1986). Unobtrusive reference testing: The 55 percent rule. Library Journal, 111, 37-41.

Houston, D. J. (2000). Public service motivation: A multivariate test. Journal of Public Administration Research \& Theory, 10(4), 713-727.

International Federation of Library Associations and Institutions. (2005a). IFLA digital reference guidelines. Retrieved January 5, 2006 from: http://www.ifla.org/ $\mathrm{VII/s36/pubs/drg03.htm.}$

International Federation of Library Associations and Institutions. (2005b). More about IFLA. Retrieved May 10, 2006 from: http://www.ifla.org/lll/intro00.htm

Kaske, N., \& Arnold, J. (2002). An unobtrusive evaluation of online real time library reference services. Retrieved February 20, 2005 from: http://www.lib.umd.edu/ groups/digref/kaskearnoldunobtrusive.html 
Koehler, W.C., \& Pemberton, J.M. (2000). A search for core values: Towards a model code of ethics for information professionals. Journal of Information Ethics 9, 2754.

LaPiere, R. T. (1934). Attitudes vs. actions. Social Forces, 13, 230-237.

Madu, C.N., \& Madu, A.A. (2002). Dimensions of E-quality. International Journal of Quality and Reliability Management, 19(3), 246-258.

Mason, R.O. (1986). Four ethical issues of the information age. Management Inform ation Systems Quarterly, 10, 5-12.

McClure, C., Lankes, R. D., Gross, M., \& Choltco-Devlin, B. (2002). Statistics, measures and quality standards for assessing digital library services: Guidelines and Procedures. ERIC Clearinghouse. Retrieved December 22, 2005 from http://quartz.syr.edu/rdlankes/tiki-download_file.php?fileld=7

O'Neill M., Wright C., \& Fitz F. (2001). Quality evaluation in on-line service environments: An application of the importance-performance measurement technique. Managing Service Quality, 11(6), 402-417.

Parasuraman, A. (1985). A conceptual model of service quality and its implications for future research. Journal of Marketing, 49, 41-50.

Parasuraman, A., Zeithaml, V. A., \& Berry, L. L. (1988). SERVQUAL: A multiple item scale for measuring consumer perceptions of service quality. Journal of Retailing, 64(1), 12-40.

Pew Internet \& American Life Project. (2005). Latest trends: Who is online. Retrieved January 28, 2006 from: http://www.pewinternet.org/trends/ User_Demo_12.05.05.htm.

Pomerantz, J. (2005). A linguistic analysis of question taxonomies. Journal of the American Society for Information Science and Technology, 56 (7), 715-728.

Radford, M. L. (2006). Encountering virtual users: A qualitative investigation of interpersonal communication in chat reference. Journal of the American Society for Information Science and Technology, 57 (8), 1046-1059.

Reference and User Services Association. (2004a). Guidelines for behavioral performance of reference and information service providers. Retrieved January 5, 2006 from: http://www.ala.org/ala/rusa/rusaprotools/referenceguide/ guidelinesbehavioral.htm

Reference and User Services Association. (2004b). Guidelines for implementing and maintaining virtual reference services. Retrieved September 20, 2005 from: http://www.ala.org/ala/rusa/rusaprotools/referenceguide/virtrefguidelines.htm.

Riesch, C., \& Kleiner, B. H. (2005). Discrimination towards customers in the restaurant industry. Equal Opportunities International, 24(7/8), 29-37.

Rubin, R. \& Froehlich, T. (1996). Ethical aspects of library and information science. In: Encyclopedia of library and information science, (Vol. 58, Suppl. 21, pp. 33-52). New York: Mercel Dekker.

Saxton, M.L., \& Richardson, J.V. (2002). Understanding reference transactions: Transforming an art into a science. San Diego, CA: Academic Press.

Smith, M. (1997). Information ethics. Annual Review of Information Science \& Technology, 32, 339-366.

Shachaf, P. (2005a). A global perspective on library association codes of ethics. Library \& Information Science Research, 27(4), 513-533. 
Shachaf, P. (2005b). Bridging cultural diversity through email. Journal of Global Information Technology Management, 8(2), 46-60.

Shachaf, P., \& Horowitz, S. (2006). Are virtual reference services color blind? Library \& Information Science Research, 28 (4), 501-520.

Sproull, L., \& Keisler, S. (1986). Reducing social context cues: Electronic mail in organizational communication. Management Science, 32, 1492-1513.

Stacy- Bates, K. (2003). E-mail reference responses from Academic ARL libraries: An unobtrusive study. Reference and User Services Quarterly, 43(1), 59-70. US Census Bureau. (2004). United States population and housing narrative profile, 2004 data set: American community survey. Retrieved January 28, 2006 from: http://factfinder.census.gov/servlet/NPTable?_bm=y\&-geo_id=01000US\&qr_name=ACS_2004_EST_G00_NP01\&-ds_name=\&-redoLog=false.

US Census Bureau. (2006). Population Finder. Retrieved June 5, 2006, from: http://www.census.gov/

Voss, C.A. (2003). Rethinking paradigms of service: Service in a virtual environment, International Journal of Operations \& Production Management, 23(1), 88-104.

Ward, D. (2003). Measuring the completeness of reference transactions in online chats: Results of an unobtrusive study. Reference and User Services Quarterly, 44(1), 46-58.

White, M. D. (2001). Digital reference services: Framework for analysis and evaluation. Library and Information Science Research, 23, 211-231.

Whitlatch, J. B. (1989). Unobtrusive studies and the quality of academic reference services. College and Research Libraries, 50(2), 181-194.

Whitlatch, J.B. (1990). Reference service effectiveness. Reference Quarterly, 30(2), 205220.

Whitlatch, J. B. (2001). Evaluating reference services in the electronic age. Library Trends, 50(2), 207-217.

Yang, Z., Jun, M., \& Peterson, R.T. (2004). Measuring costumer perceived online service quality: Scale development and managerial implications. International Journal of Operations \& Production Management, 24(11/12), 1149-1174. 
Table 1. Public libraries study data collection table Questions sent to participating institutions

\begin{tabular}{|l|l|l|l|l|}
\hline & Week 1 & Week 2 & Week 3 & Week 4 \\
\hline $\begin{array}{l}\text { First set of } \\
\text { institutions }\end{array}$ & $\begin{array}{l}\text { Question 1 from } \\
\text { female } \\
\text { Caucasian }\end{array}$ & $\begin{array}{l}\text { Question 2 from } \\
\text { female African- } \\
\text { American }\end{array}$ & $\begin{array}{l}\text { Question 3 from } \\
\text { male Caucasian }\end{array}$ & $\begin{array}{l}\text { Question 4 from } \\
\text { male African- } \\
\text { American }\end{array}$ \\
\hline $\begin{array}{l}\text { Second set of } \\
\text { institutions }\end{array}$ & $\begin{array}{l}\text { Question 2 from } \\
\text { female } \\
\text { Caucasian }\end{array}$ & $\begin{array}{l}\text { Question 3 from } \\
\text { female African- } \\
\text { American }\end{array}$ & $\begin{array}{l}\text { Question 4 from } \\
\text { male Caucasian }\end{array}$ & $\begin{array}{l}\text { Question 1 from } \\
\text { male African- } \\
\text { American }\end{array}$ \\
\hline $\begin{array}{l}\text { Third set of } \\
\text { institutions }\end{array}$ & $\begin{array}{l}\text { Question 3 from } \\
\text { female } \\
\text { Caucasian }\end{array}$ & $\begin{array}{l}\text { Question 4 from } \\
\text { female African- } \\
\text { American }\end{array}$ & $\begin{array}{l}\text { Question 1 from } \\
\text { male Caucasian }\end{array}$ & $\begin{array}{l}\text { Question 2 from } \\
\text { male African- } \\
\text { American }\end{array}$ \\
\hline $\begin{array}{l}\text { Fourth set of } \\
\text { institutions }\end{array}$ & $\begin{array}{l}\text { Question 4 from } \\
\text { female } \\
\text { Caucasian }\end{array}$ & $\begin{array}{l}\text { Question 1 from } \\
\text { female African- } \\
\text { American }\end{array}$ & $\begin{array}{l}\text { Question 2 from } \\
\text { male Caucasian }\end{array}$ & $\begin{array}{l}\text { Question 3 from } \\
\text { male African- } \\
\text { American }\end{array}$ \\
\hline
\end{tabular}


Table 2. Coding scheme

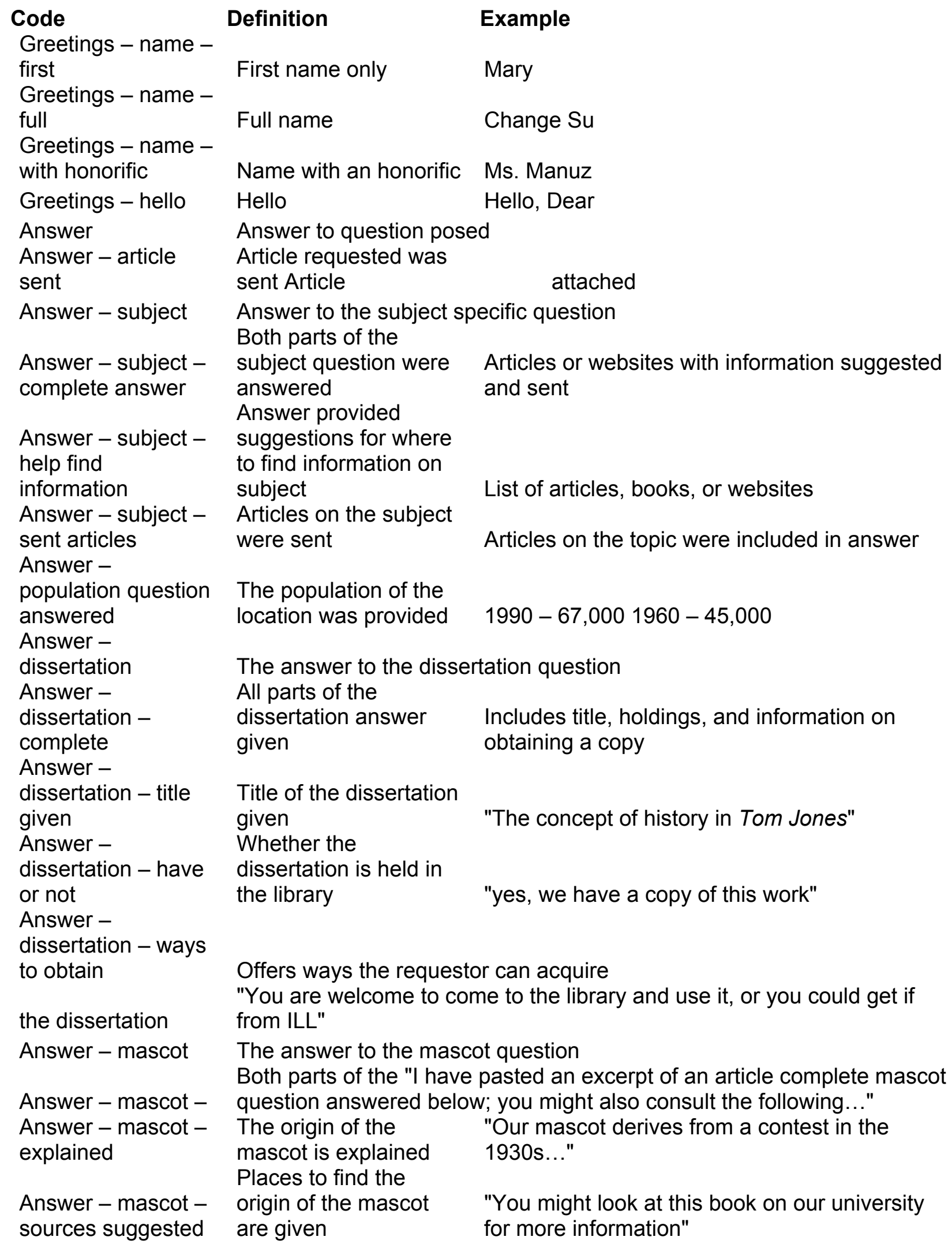




\begin{tabular}{|c|c|c|}
\hline $\begin{array}{l}\text { Answer - chapter } \\
\text { sent }\end{array}$ & $\begin{array}{l}\text { The requested chapter } \\
\text { was sent }\end{array}$ & "The pages you requested are attached" \\
\hline $\begin{array}{l}\text { Answer/Caring for } \\
\text { Roses }\end{array}$ & Question \#3 answered & \\
\hline $\begin{array}{l}\text { Answer/Caring for } \\
\text { Roses/Reference }\end{array}$ & $\begin{array}{l}\text { Interview Attempted } \\
\text { Provides multiple }\end{array}$ & Reference interview was attempted \\
\hline $\begin{array}{l}\text { Answer/Caring for } \\
\text { Roses/Complete }\end{array}$ & $\begin{array}{l}\text { sources and } \\
\text { bibliographic data or } \\
\text { links } \\
\text { Only one source } \\
\text { given, or no }\end{array}$ & $\begin{array}{l}\text { I have attached three websites on the care of } \\
\text { roses and three books that are in our library } \\
\text { catalog... }\end{array}$ \\
\hline $\begin{array}{l}\text { Answer/Caring for } \\
\text { Roses/Partial } \\
\text { Answer/Temperatur } \\
\text { e in London } \\
\text { Answer/Temperatur } \\
\text { e in }\end{array}$ & $\begin{array}{l}\text { bibliographic data or } \\
\text { links Absolutely! } \\
\text { Question \#4 answered }\end{array}$ & \\
\hline London/Accurate & Matches our data & $\begin{array}{l}8-17 \mathrm{C} \text { or } 46.4-62.6 \mathrm{~F} \\
\text { According to www.worldclimate.com , the }\end{array}$ \\
\hline Answer/Temperatur & Provides temperature & $\begin{array}{l}\text { average temperature at the London/Heathrow } \\
\text { Airport area in the month of May is } 54.7\end{array}$ \\
\hline $\begin{array}{l}\text { Answer/Temperatur } \\
\text { e in London/Partial } \\
\text { Answer/Town }\end{array}$ & $\begin{array}{l}\text { No temperature given, } \\
\text { or no source cited }\end{array}$ & $\begin{array}{l}\text { To see average monthly temperatures for } \\
\text { London, look here:... }\end{array}$ \\
\hline $\begin{array}{l}\text { Population } \\
\text { Answer/Town } \\
\text { Population/Accurat }\end{array}$ & Question \#1 answered & \\
\hline $\begin{array}{l}\text { e } \\
\text { Answer/Town }\end{array}$ & Matches our data & According to the Census Bureau \\
\hline $\begin{array}{l}\text { Population/Complet } \\
\text { e } \\
\text { Answer/Town }\end{array}$ & $\begin{array}{l}\text { Provides population } \\
\text { and cites source } \\
\text { No population given, }\end{array}$ & $\begin{array}{l}\text { (factfinder.census.gov), [Town name]'s } \\
\text { population in } 2000 \text { was [number] persons. }\end{array}$ \\
\hline $\begin{array}{l}\text { Population/Partial } \\
\text { Answer/Library Has }\end{array}$ & or no source cited & The population was [Number] \\
\hline RJ or HP & Question \#2 answered & \\
\hline
\end{tabular}


Table 3. Academic libraries study frequency and percent of code by user name

\begin{tabular}{|c|c|c|c|c|c|c|c|}
\hline \multicolumn{2}{|c|}{ Variable C $\phi$ de } & \multirow{2}{*}{$\begin{array}{l}\text { Mary } \\
20 \\
(37 \%)\end{array}$} & \multirow{2}{*}{$\begin{array}{l}\text { Moshe } \\
21 \\
(38 \%)\end{array}$} & \multirow{2}{*}{$\begin{array}{l}\text { Ahmed } \\
23 \\
(42 \%)\end{array}$} & \multirow{2}{*}{$\begin{array}{l}\text { Latoya } \\
23 \\
(42 \%)\end{array}$} & \multirow{2}{*}{$\begin{array}{l}\text { Rosa } \\
26 \\
(48 \%)\end{array}$} & \multirow{2}{*}{$\begin{array}{l}\text { Chang } \\
9 \\
(16 \%)\end{array}$} \\
\hline Courtesy & Greetings/ first name $(\mathrm{N}=324)$ & & & & & & \\
\hline & Greetings/ full name $(\mathrm{N}=324)$ & $\begin{array}{l}4 \\
(7 \%)\end{array}$ & $\begin{array}{l}3 \\
(5 \%)\end{array}$ & $\begin{array}{l}3 \\
(5 \%)\end{array}$ & $\begin{array}{l}1 \\
(2 \%)\end{array}$ & $\begin{array}{l}3 \\
(5 \%)\end{array}$ & $\begin{array}{l}13 \\
(24 \%)\end{array}$ \\
\hline & $\begin{array}{l}\text { Greetings/ with honorific } \\
(\mathrm{N}=324)\end{array}$ & $\begin{array}{l}8 \\
(15 \%)\end{array}$ & $\begin{array}{l}4 \\
(7 \%)\end{array}$ & $\begin{array}{l}2 \\
(4 \%)\end{array}$ & $\begin{array}{l}5 \\
(9 \%)\end{array}$ & $\begin{array}{l}6 \\
(11 \%)\end{array}$ & $\begin{array}{l}0 \\
(0 \%)\end{array}$ \\
\hline & Greetings/ hello $(\mathrm{N}=324)$ & $\begin{array}{l}28 \\
(52 \%)\end{array}$ & $\begin{array}{l}26 \\
(48 \%)\end{array}$ & $\begin{array}{l}25 \\
(46 \%)\end{array}$ & $\begin{array}{l}31 \\
(57 \%)\end{array}$ & $\begin{array}{l}32 \\
(59 \%)\end{array}$ & $\begin{array}{l}24 \\
(44 \%)\end{array}$ \\
\hline & Thank you for using $(\mathrm{N}=324)$ & $\begin{array}{l}18 \\
(33 \%)\end{array}$ & $\begin{array}{l}16 \\
(30 \%)\end{array}$ & $\begin{array}{l}12 \\
(22 \%)\end{array}$ & $\begin{array}{l}14 \\
(26 \%)\end{array}$ & $\begin{array}{l}20 \\
(37 \%)\end{array}$ & $\begin{array}{l}16 \\
(30 \%)\end{array}$ \\
\hline \multirow[t]{4}{*}{ Reliability } & Complete response $(\mathrm{N}=324)$ & $\begin{array}{l}23 \\
(42 \%)\end{array}$ & $\begin{array}{l}22 \\
(41 \%)\end{array}$ & $\begin{array}{l}18 \\
(33 \%)\end{array}$ & $\begin{array}{l}20 \\
(37 \%)\end{array}$ & $\begin{array}{l}20 \\
(37 \%)\end{array}$ & $\begin{array}{l}22 \\
(41 \%)\end{array}$ \\
\hline & Accurate response $(\mathrm{N}=117)$ & $\begin{array}{l}17 \\
(32 \%)\end{array}$ & $\begin{array}{l}12 \\
(22 \%)\end{array}$ & $\begin{array}{l}11 \\
(20 \%)\end{array}$ & $\begin{array}{l}13 \\
(24 \%)\end{array}$ & $\begin{array}{l}17 \\
(32 \%)\end{array}$ & $\begin{array}{l}16 \\
(30 \%)\end{array}$ \\
\hline & Answer/ article sent $(\mathrm{N}=58)$ & $\begin{array}{l}0 \\
(0 \%)\end{array}$ & $\begin{array}{l}1 \\
(2 \%)\end{array}$ & $\begin{array}{l}4 \\
(7 \%)\end{array}$ & $\begin{array}{l}2 \\
(4 \%)\end{array}$ & $\begin{array}{l}0 \\
(0 \%)\end{array}$ & $\begin{array}{l}2 \\
(4 \%)\end{array}$ \\
\hline & $\begin{array}{l}\text { Answer/ population question } \\
\text { answered }(\mathrm{N}=59)\end{array}$ & $\begin{array}{l}8 \\
(15 \%)\end{array}$ & $\begin{array}{l}5 \\
(9 \%)\end{array}$ & $\begin{array}{l}7 \\
(13 \%)\end{array}$ & $\begin{array}{l}4 \\
(7 \%)\end{array}$ & $\begin{array}{l}8 \\
(15 \%)\end{array}$ & $\begin{array}{l}8 \\
(15 \%)\end{array}$ \\
\hline \multirow[t]{6}{*}{ Answer/ } & $\begin{array}{l}\text { dissertation/ } \\
\text { complete }(\mathrm{N}=58)\end{array}$ & $\begin{array}{l}8 \\
(15 \%)\end{array}$ & $\begin{array}{l}8 \\
(15 \%)\end{array}$ & $\begin{array}{l}6 \\
(11 \%)\end{array}$ & $\begin{array}{l}8 \\
(15 \%)\end{array}$ & $\begin{array}{l}7 \\
(13 \%)\end{array}$ & $\begin{array}{l}7 \\
(13 \%)\end{array}$ \\
\hline & $\begin{array}{l}\text { Answer/ dissertation/ title } \\
\text { given }(\mathrm{N}=58)\end{array}$ & $\begin{array}{l}2 \\
(4 \%)\end{array}$ & $\begin{array}{l}1 \\
(2 \%)\end{array}$ & $\begin{array}{l}1 \\
(2 \%)\end{array}$ & $\begin{array}{l}2 \\
(4 \%)\end{array}$ & $\begin{array}{l}2 \\
(4 \%)\end{array}$ & $\begin{array}{l}3 \\
(5 \%)\end{array}$ \\
\hline & $\begin{array}{l}\text { Answer/ dissertation/ have or } \\
\text { not }(\mathrm{N}=58)\end{array}$ & $\begin{array}{l}1 \\
(2 \%)\end{array}$ & $\begin{array}{l}0 \\
(0 \%)\end{array}$ & $\begin{array}{l}0 \\
(0 \%)\end{array}$ & $\begin{array}{l}0 \\
(0 \%)\end{array}$ & $\begin{array}{l}0 \\
(05)\end{array}$ & $\begin{array}{l}2 \\
(4 \%)\end{array}$ \\
\hline & $\begin{array}{l}\text { Answer/ dissertation/ ways to } \\
\text { obtain }(\mathrm{N}=58)\end{array}$ & $\begin{array}{l}1 \\
(2 \%)\end{array}$ & $\begin{array}{l}1 \\
(2 \%)\end{array}$ & $\begin{array}{l}2 \\
(4 \%)\end{array}$ & $\begin{array}{l}2 \\
(4 \%)\end{array}$ & $\begin{array}{l}1 \\
(2 \%)\end{array}$ & $\begin{array}{l}1 \\
(2 \%)\end{array}$ \\
\hline & $\begin{array}{l}\text { Answer/ mascot/ explained } \\
(\mathrm{N}=59)\end{array}$ & $\begin{array}{l}2 \\
(4 \%)\end{array}$ & $\begin{array}{l}3 \\
(5 \%)\end{array}$ & $\begin{array}{l}0 \\
(0 \%)\end{array}$ & $\begin{array}{l}1 \\
(2 \%)\end{array}$ & $\begin{array}{l}2 \\
(4 \%)\end{array}$ & $\begin{array}{l}0 \\
(0 \%)\end{array}$ \\
\hline & $\begin{array}{l}\text { Answer/ mascot/ sources } \\
\text { suggested }(\mathrm{N}=59)\end{array}$ & $\begin{array}{l}1 \\
(2 \%)\end{array}$ & $\begin{array}{l}1 \\
(2 \%)\end{array}$ & $\begin{array}{l}2 \\
(4 \%)\end{array}$ & $\begin{array}{l}3 \\
(5 \%)\end{array}$ & $\begin{array}{l}3 \\
(5 \%)\end{array}$ & $\begin{array}{l}2 \\
(4 \%)\end{array}$ \\
\hline
\end{tabular}




\begin{tabular}{|l|l|l|l|l|l|l|l|}
\hline & $\begin{array}{l}\text { Answer/ mascot/ complete } \\
(\mathrm{N}=59)\end{array}$ & $\begin{array}{l}2 \\
(4 \%)\end{array}$ & $\begin{array}{l}3 \\
(5 \%)\end{array}$ & $\begin{array}{l}0 \\
(0 \%)\end{array}$ & $\begin{array}{l}1 \\
(2 \%)\end{array}$ & $\begin{array}{l}3 \\
(5 \%)\end{array}$ & $\begin{array}{l}4 \\
(7 \%)\end{array}$ \\
\hline $\begin{array}{l}\text { Answer/ book chapter sent } \\
(\mathrm{N}=31)\end{array}$ & $\begin{array}{l}0 \\
(0 \%)\end{array}$ & $\begin{array}{l}0 \\
(0 \%)\end{array}$ & $\begin{array}{l}0 \\
(0 \%)\end{array}$ & $\begin{array}{l}1 \\
(2 \%)\end{array}$ & $\begin{array}{l}0 \\
(0 \%)\end{array}$ & $\begin{array}{l}0 \\
(0 \%)\end{array}$ \\
\hline $\begin{array}{l}\text { Closure/ Name of librarian } \\
(\mathrm{N}=324)\end{array}$ & $\begin{array}{l}33 \\
(61 \%)\end{array}$ & $\begin{array}{l}29 \\
(53 \%)\end{array}$ & $\begin{array}{l}32 \\
(59 \%)\end{array}$ & $\begin{array}{l}36 \\
(67 \%)\end{array}$ & $\begin{array}{l}42 \\
(78 \%)\end{array}$ & $\begin{array}{l}32 \\
(59 \%)\end{array}$ \\
\hline & $\begin{array}{l}\text { Closure/ Initial of librarian } \\
(\mathrm{N}=324)\end{array}$ & $\begin{array}{l}6 \\
(11 \%)\end{array}$ & $\begin{array}{l}5 \\
(9 \%)\end{array}$ & $\begin{array}{l}5 \\
(9 \%)\end{array}$ & $\begin{array}{l}5 \\
(9 \%)\end{array}$ & $\begin{array}{l}3 \\
(5 \%)\end{array}$ & $\begin{array}{l}6 \\
(11 \%)\end{array}$ \\
\hline & $\begin{array}{l}\text { Closure/ Department (N=324) } \\
(65 \%)\end{array}$ & $\begin{array}{l}31 \\
(57 \%)\end{array}$ & $\begin{array}{l}33 \\
(61 \%)\end{array}$ & $\begin{array}{l}36 \\
(67 \%)\end{array}$ & $\begin{array}{l}36 \\
(67 \%)\end{array}$ & $\begin{array}{l}31 \\
(57 \%)\end{array}$ \\
\hline
\end{tabular}


Table 4. Responsiveness by user group

\begin{tabular}{|c|c|c|c|}
\hline & & \multicolumn{2}{|c|}{ Response time (number of hours) ${ }^{*}$} \\
\hline Study Name & & Mean & Standard Deviation \\
\hline Academic Mary & $\begin{array}{l}\text { Anderson } \\
(\mathrm{N}=54)^{*}\end{array}$ & 31.386 .2 & \\
\hline Moshe & $\begin{array}{c}\text { Cohen } \\
(\mathrm{N}=54)^{*}\end{array}$ & 24.757 .78 & \\
\hline Ahmed & $\begin{array}{l}\text { Ibrahim } \\
(\mathrm{N}=54)^{*}\end{array}$ & 15.125 .27 & \\
\hline \multirow[t]{3}{*}{ Latoya } & $\begin{array}{c}\text { Johnson } \\
(\mathrm{N}=54)^{*}\end{array}$ & 28.226 .03 & \\
\hline & Rosa Manuz $(\mathrm{N}=54)^{*}$ & 9.77 & 3.23 \\
\hline & Chang Su $(\mathrm{N}=54)^{*}$ & 18.01 & 5.98 \\
\hline \multirow[t]{2}{*}{ Public } & Latoya Jones $(\mathrm{N}=88)^{*}$ & 18.74 & 60.78 \\
\hline & Emily Baker $(\mathrm{N}=88)^{*}$ & 15.32 & 29.09 \\
\hline \multirow[t]{2}{*}{ Tyrone } & $\begin{array}{l}\text { Johnson } \\
(\mathrm{N}=88)^{*}\end{array}$ & 12.1217 .84 & \\
\hline & Todd Kelly $(\mathrm{N}=88)^{*}$ & 26.16 & 65.73 \\
\hline
\end{tabular}

* No response was calculated as 200 hours to avoid misinterpretation of the value 0 in the response time attribute. 
Table 5. Public libraries study frequencies and percent of codes by user name

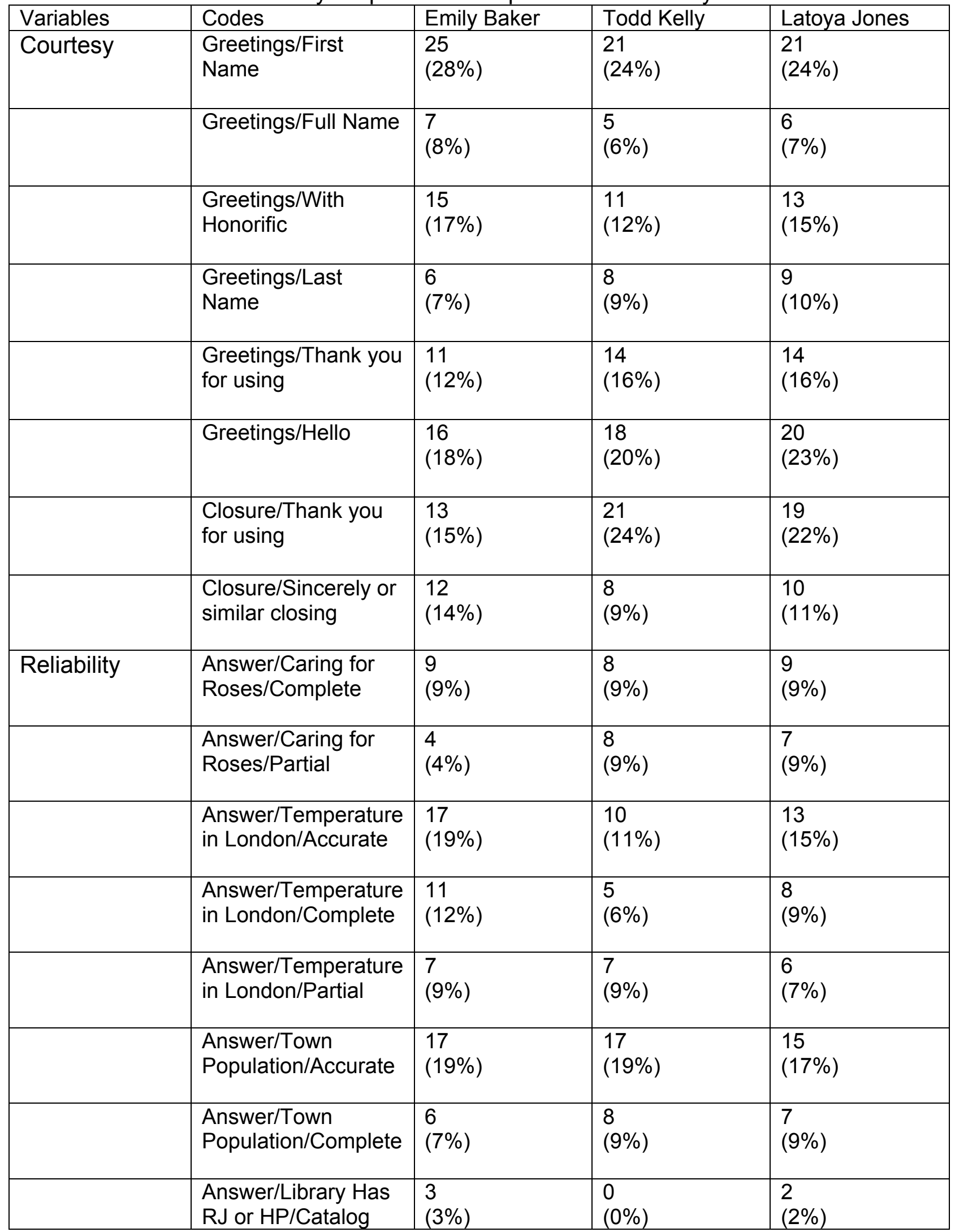




\begin{tabular}{|l|l|l|l|l|}
\hline & Instruction Given & & & 1 \\
& $\begin{array}{l}\text { Answer/Library Has } \\
\text { RJ or HP/Complete }\end{array}$ & $\begin{array}{l}3 \\
(3 \%)\end{array}$ & $\begin{array}{l}1 \\
(1 \%)\end{array}$ & $(1 \%)$ \\
\hline & $\begin{array}{l}\text { Answer/Library Has } \\
\text { RJ or HP/Partial }\end{array}$ & $\begin{array}{l}11 \\
(12 \%)\end{array}$ & $\begin{array}{l}15 \\
(17 \%)\end{array}$ & $\begin{array}{l}15 \\
(17 \%)\end{array}$ \\
\hline & $\begin{array}{l}\text { Closure/Name of } \\
\text { Librarian }\end{array}$ & $\begin{array}{l}42 \\
(48 \%)\end{array}$ & $\begin{array}{l}44 \\
(50 \%)\end{array}$ & $\begin{array}{l}43 \\
(49 \%)\end{array}$ \\
\hline & $\begin{array}{l}\text { Closure/Department } 27 \\
(31 \%)\end{array}$ & $\begin{array}{l}23 \\
(26 \%)\end{array}$ & $\begin{array}{l}22 \\
(25 \%)\end{array}$ \\
\hline & $\begin{array}{l}\text { Closure/Library } \\
\text { Name }\end{array}$ & $\begin{array}{l}39 \\
(44 \%)\end{array}$ & $\begin{array}{l}41 \\
(47 \%)\end{array}$ & $\begin{array}{l}43 \\
(49 \%)\end{array}$ \\
\hline & Closure/Contact Info & $\begin{array}{l}33 \\
(37 \%)\end{array}$ & $\begin{array}{l}33 \\
(37 \%)\end{array}$ & 33 \\
& $\begin{array}{l}\text { Closure/Librarian } \\
\text { initials }\end{array}$ & $\begin{array}{l}5 \\
(6 \%)\end{array}$ & $\begin{array}{l}3 \\
(3 \%)\end{array}$ \\
\hline & $\begin{array}{l}\text { Closure/Job Title } \\
(33 \%)\end{array}$ & $\begin{array}{l}29 \\
(33 \%)\end{array}$ & $\begin{array}{l}24 \\
(2 \%)\end{array}$ \\
\hline
\end{tabular}


Table 6. Cross tabulation results for public libraries study by user

\begin{tabular}{|c|c|c|c|c|}
\hline Variable & $\begin{array}{l}\text { Code } \\
(\mathrm{N}=352, \mathrm{df}=3)\end{array}$ & Pearson $\chi^{2}$ & Cramer's V & $p$ value \\
\hline \multirow[t]{8}{*}{ Courtesy } & $\begin{array}{l}\text { Greetings/ First } \\
\text { Name }\end{array}$ & .901 & .051 & .825 \\
\hline & $\begin{array}{l}\text { Greetings/ Full } \\
\text { Name }\end{array}$ & 1.404 & .063 & .705 \\
\hline & $\begin{array}{l}\text { Greetings/ With } \\
\text { Honorific }\end{array}$ & 4.500 & .113 & .212 \\
\hline & $\begin{array}{l}\text { Greetings/ Last } \\
\text { Name }\end{array}$ & 5.310 & .123 & .150 \\
\hline & $\begin{array}{l}\text { Greetings/Thank } \\
\text { you }\end{array}$ & .787 & .047 & .852 \\
\hline & $\begin{array}{l}\text { Greetings/ Greeting } \\
\text { Hello }\end{array}$ & 1.616 & .068 & .656 \\
\hline & Closure/Thank you & 2.452 & .083 & .484 \\
\hline & \multicolumn{2}{|c|}{ Closure/Sincerely 2.726} & .088 & .436 \\
\hline \multirow[t]{8}{*}{ Reliability } & Answer/ Complete & 2.769 & .089 & .429 \\
\hline & Answer/ Accurate & 1.46 & .064 & .692 \\
\hline & Answer/ Partial & .373 & .033 & .946 \\
\hline & $\begin{array}{l}\text { Closure/Name of } \\
\text { Librarian }\end{array}$ & .124 .019 & & .989 \\
\hline & Closure/Department & .962 .052 & & .811 \\
\hline & $\begin{array}{l}\text { Closure/Library } \\
\text { Name }\end{array}$ & 1.593 .067 & & .661 \\
\hline & $\begin{array}{l}\text { Closure/Contact } \\
\text { Info }\end{array}$ & .896 .050 & & .826 \\
\hline & Closure/Job Title & .899 & .051 & .826 \\
\hline
\end{tabular}


Table 7. Cross tabulation results of public libraries study by gender and ethnicity

\begin{tabular}{|c|c|c|c|c|c|}
\hline Variable & Code & Gender & & Ethnicity & \\
\hline & & Pearson $\chi 2$ & Cramer's V & Pearson $\chi^{2}$ & Cramer's V \\
\hline Courtesy & $\begin{array}{l}\text { Greetings/ First } \\
\text { Name }\end{array}$ & .431 & .036 & .586 & .072 \\
\hline & $\begin{array}{l}\text { Greetings/ Full } \\
\text { Name }\end{array}$ & .040 & .011 & .363 & .033 \\
\hline & $\begin{array}{l}\text { Greetings/ With } \\
\text { Honorific }\end{array}$ & .325 & .031 & 1.302 & .063 \\
\hline & $\begin{array}{l}\text { Greetings/ Last } \\
\text { Name }\end{array}$ & 1.9 & .076 & 2.97 & .095 \\
\hline & $\begin{array}{l}\text { Greetings/ } \\
\text { Thank you }\end{array}$ & .354 & .033 & .354 & .033 \\
\hline & Greetings/ Hello & .296 & .030 & .000 & .000 \\
\hline & $\begin{array}{l}\text { Closure/ Thank } \\
\text { You }\end{array}$ & .878 .054 .161 & .022 & & \\
\hline & $\begin{array}{l}\text { Closure/ } \\
\text { Sincerely }\end{array}$ & . 579.042 .643 & .044 & & \\
\hline Reliability & Complete & .014 .006 .345 & 032 & & \\
\hline & Partial & .000 .000 .110 & 018 & & \\
\hline & Accurate & 250.027 .118 & .019 & & \\
\hline & $\begin{array}{l}\text { Closure/ Name } \\
\text { of Librarian }\end{array}$ & .048 .012 .000 & .000 & & \\
\hline & $\begin{array}{l}\text { Closure/ } \\
\text { Department }\end{array}$ & .000 .000 .058 & 013 & & \\
\hline & $\begin{array}{l}\text { Closure/ Library } \\
\text { Name }\end{array}$ & .434 .0361 .206 & & & .060 \\
\hline & $\begin{array}{l}\text { Closure/ } \\
\text { Contact Info }\end{array}$ & .713 .047 .713 . & .047 & & \\
\hline & $\begin{array}{l}\text { Closure/ } \\
\text { Librarian Initials }\end{array}$ & .000 .000 .298 & .030 & & \\
\hline & $\begin{array}{l}\text { Closure/ Job } \\
\text { Title }\end{array}$ & .218 .026 .489 & .038 & & \\
\hline
\end{tabular}

$\mathrm{N}=352$

${ }^{*} p<.05$

${ }^{* *} p<.01$ 
Table 8. Differences between the pilot study (Shachaf \& Horowitz, 2006) and the current Study

\begin{tabular}{|c|c|c|}
\hline Pilot & study & Current study \\
\hline Sample - libraries & $\begin{array}{l}\text { Total - } 23 \text { libraries } \\
\text { 1. ARL libraries - } 23\end{array}$ & $\begin{array}{l}\text { Total - } 142 \text { libraries } \\
\text { 1. Public libraries - } 88 \\
\text { libraries } \\
\text { 2. Carnegie } \\
\text { doctoral/research } \\
\text { universities extensive } \\
\text { and doctoral/research } \\
\text { universities - } \\
\text { intensive - } 54\end{array}$ \\
\hline $\begin{array}{l}\text { Sample - number of } \\
\text { transactions }\end{array}$ & Total - 138 & $\begin{array}{l}\text { Total - } 676 \\
324 \text { - academic libraries } \\
352 \text { - public libraries }\end{array}$ \\
\hline Manipulation & 6 user names & $\begin{array}{l}\text { Gender } \\
\text { Ethnicity } \\
10 \text { user names ( } 6 \text { academic } \\
\text { libraries; } 4 \text { public libraries) }\end{array}$ \\
\hline Measures & $\begin{array}{l}\text { Content analysis based on } \\
\text { RUSA and IFLA guidelines }\end{array}$ & $\begin{array}{l}\text { Reliability, timely response, } \\
\text { and courtesy. }\end{array}$ \\
\hline Hypotheses & None & 3 hypotheses \\
\hline Data analysis & frequencies & t-test and cross tabulation \\
\hline Findings & $\begin{array}{l}\text { Discrimination against } \\
\text { African-American and Arabs }\end{array}$ & $\begin{array}{l}\text { Equality of service to all user } \\
\text { groups (statistically } \\
\text { significant) }\end{array}$ \\
\hline
\end{tabular}

